\title{
Ex vivo expansion of human peripheral blood natural killer cells and cytotoxic $T$ lymphocytes from lung cancer patients
}

\author{
HOANG THI MY NHUNG ${ }^{1,2 *}$, BUI VIET ANH ${ }^{1 *}$, TRUONG LINH HUYEN $^{1}$, DOAN TRUNG HIEP ${ }^{3}$, \\ CHU THI THAO ${ }^{1}$, PHUNG NAM LAM ${ }^{3}$ and NGUYEN THANH LIEM ${ }^{1}$ \\ ${ }^{1}$ Department of Stem Cell and Immune Cell, Vinmec Research Institute of Stem Cells and Gene Technology; \\ ${ }^{2}$ Department of Cell Biology, Faculty of Biology, VNU University of Science; ${ }^{3}$ Department of \\ Oncology, Vinmec International Hospital, Hanoi 100000, Vietnam
}

Received August 8, 2017; Accepted January 3, 2018

DOI: $10.3892 / \mathrm{ol} .2018 .8029$

\begin{abstract}
Lung cancer is the most common type of cancer with the highest cancer-associated mortality rates worldwide, as well as in Vietnam. Numerous studies have demonstrated that higher numbers and higher rate of activity of infiltrating natural killer (NK) cells and cytotoxic T lymphocytes (CTLs) in the tumor are closely correlated with positive prognosis, tumor size decrease and longer survival of lung cancer patients. In the present study, the effectiveness of BINKIT ${ }^{\circledR}$ kit in the ex vivo expansion of NK cells and CTLs in the peripheral blood of 7 patients aged between 30 and 84 years with metastatic lung cancer was evaluated. After 21 days of culture, the average number of CTLs $\left(\mathrm{CD}^{+} \mathrm{CD}^{+}\right)$increased by 742.3 -fold in the CTL culture, accounting for $72.2 \%$ of the cultured cell population, and the mean cell viability was $95.7 \%$. In the NK cell culture, the average number of NK cells $\left(\mathrm{CD}^{-} \mathrm{CD}^{-} 6^{+}\right)$increased by 637.5 -fold, accounting for $84.3 \%$ of the cultured cell population, with an average viability of $94.7 \%$. The percentage of active NK cells (CD3 ${ }^{-} \mathrm{CD}^{-} 6^{+}$bright) was $82.1 \%$, which increased by 408.9 -fold. Notably, a close correlation was identified between the numbers of cytokine-induced killer $\left(\mathrm{CD}^{+}{ }^{+} \mathrm{CD} 56^{+}\right)$and $\mathrm{NK}\left(\mathrm{CD} 3^{-} \mathrm{CD} 56^{+}\right)$cells in the $\mathrm{NK}$ cell culture $(\mathrm{P}<0.05)$. In the two culture conditions (namely NK cell and CTL cultures), no clear correlation was identified between the rate of initial immune cells in the peripheral blood and the corresponding number following ex vivo expansion $(\mathrm{P}>0.05)$. These results revealed that the method of expansion and activation of NK cells and CTLs from peripheral blood was
\end{abstract}

Correspondence to: Professor Nguyen Thanh Liem, Department of Stem Cell and Immune Cell, Vinmec Research Institute of Stem Cells and Gene Technology, 458 Minh Khai, Hanoi 100000, Vietnam

E-mail:v.liemnt@vinmec.com

*Contributed equally

Key words: natural killer cells, cytotoxic T lymphocytes, lung cancer, cytokine-induced killer cells, peripheral blood mononuclear cells successfully applied using BINKIT, and reached the requirements for clinical applications in cancer treatment in Vietnam.

\section{Introduction}

According to 2012 report of the World Health Organization (1), cancer is the leading cause of morbidity and mortality worldwide. Lung cancer is the most common type of cancer and results in the highest cancer-associated mortality rate worldwide, as well as in Vietnam (1). Traditional cancer treatments, including surgery, chemotherapeutic agents and ionizing radiation, have been used to eliminate tumors in patients. However, the rising resistance to drugs or radiation leads to metastasis of cancer cells and reduces the survival rate of patients with cancer.

In the past few years, cancer immunotherapy has been considered to be a novel promising method for cancer treatment, particularly when combined with other traditional methods $(2,3)$. Immunotherapy increases the strength of immune responses against tumors by stimulating the activities of specific components of the immune system. Based on the function of immune cells in targeting cancer, the autologous immune enhancement therapy (AIET) involves multiplying autologous immune cells ex vivo and injecting them into the body in order to destroy the cancer cells (2-4). Several studies have demonstrated that the higher number and higher rate of activity of infiltrating natural killer (NK) cells and cytotoxic $\mathrm{T}$ lymphocytes (CTLs) to the tumor are closely correlated with positive prognosis, tumor size decrease and longer survival of patients with cancer $(5,6)$.

NK cells, first identified in 1975 as a unique lymphocyte subset, have the morphology of large granular lymphocytes, and are capable of recognizing and killing abnormalities that are missing or not expressing the 'self' markers of major histocompatibility complex class I. These cells are characterized by the expression of CD56 and the lack of CD3 expression (termed $\mathrm{CD} 6^{+} \mathrm{CD} 3^{-}$lymphocytes), which can also be distinguished according to the level of CD56 expression as CD56 $6^{\text {bright }}$ and CD56 $6^{\mathrm{dim}}$ subsets (7). NK cells directly kill target tumor cells through the apoptosis mechanism by releasing cytoplasmic granules containing perforin and granzymes, or by expressing death receptor ligands on their 
cell surface (8). In addition, NK cells secrets various effective molecules, including interferon (IFN) $-\gamma$, and function in coordination with other immune cells, such as dendritic cells and $\mathrm{T}$ lymphocyte, to exert antitumor functions in various manners $(9,10)$. In cancer patients, the NK cell number in the peripheral blood and tumor infiltrate, as well as the cytokine production and expression of activating receptors, are decreased; by contrast, the inhibitory receptors are overexpressed (10).

CTLs, also known as $\mathrm{CD}^{+}$or killer T cells, are characterized by the expression of $\mathrm{CD} 3$ and $\mathrm{CD} 8\left(\mathrm{CD} 3^{+} \mathrm{CD} 8^{+}\right)$. These cells are a critical component of adaptive immunity to destroy infected or malignant cells. CTLs secrete cytokines including primarily tumor necrosis factor (TNF)- $\alpha$ and IFN- $\gamma$, which have antitumor and anti-viral microbial effects. Another major function of CTLs is the production and release of cytotoxic granules, which are also found in NK cells and contain two families of proteins, namely perforin and granzymes. Furthermore, CTLs also cause the destruction of infected cells via the Fas/FasL interaction (11-15).

The AIET method mainly uses a dual combination of NK cells and CTLs, as they have a definite advantage in targeting abnormal expressing MHC class I and MHC antigen expressing cancer cells. In addition, NK cells and CTLs preferentially kill cancer stem cells, which is an added benefit to their use, since cancer stem cells are resistant to the majority of therapies and serve a major role in cancer recurrence (16-18). Considering this evidence, it is suggested that AIET would be an effective treatment method for cancer patients by destroying circulating tumor cells, thereby preventing metastasis and cancer recurrence. For AIET, obtaining a sufficient number of functional immune cells is critical in clinical protocols. Therefore, the number and purity of expanded immune cells is considered as a key factor. Several researchers have attempted the use of various methods to achieve large-scale NK cell and CTL ex vivo expansion (19-23), and have applied these methods in clinical trials with positive results reported in India, Japan and China (18,24-26).

The aim of the present study is to evaluate the effectiveness of BINKIT ${ }^{\circledR}$ for the expansion of NK cells and CTLs collected from the peripheral blood of Vietnamese patients with lung cancer for the application of AIET. The BINKIT medium was successfully developed by the Biotherapy Institute of Japan (Tokyo, Japan). The use of this medium for immune cell expansion and activation in AIET in clinical applications has been previously examined $(4,25,26)$. To the best of our knowledge, the present study is the first to identify the use of BINKIT for AIET in lung cancer.

\section{Materials and methods}

Patients. A total of 7 patients with lung cancer with an Eastern Cooperative Oncology Group/Performance Status (ECOG/PG) of $\geq 3$, who were admitted to the Department of Oncology of the Vinmec International Hospital (Hanoi, Vietnam) between April 2016 and August 2016, were enrolled into the present study. The exclusion criteria included severe infection, autoimmune disease, use of anti-rejection drugs or $\mathrm{T}$ cell lymphomas. Patients provided a written informed consent, and the study was approved by the Ethics Committee of the
Vinmec International Hospital. This study was conducted with the permission of the Vietnam Ministry of Health (document no. 2517/BYT-KCB; Hanoi, Vietnam). In total, 7 peripheral blood samples were obtained and marked as PT1 to PT7, corresponding to the 7 patients.

Isolation and large-scale expansion of NK cells and CTLs from peripheral blood. Peripheral blood mononuclear cells (PBMNCs) were obtained from the peripheral blood sample (70 ml) of each cancer patient by density gradient centrifugation using Ficoll-Paque media (GE Healthcare Life Sciences, Uppsala, Sweden) following the manufacturer's instructions. Subsequently, PBMNCs were cultured using BINKIT (Biotherapy Institute of Japan, Japan). Briefly, the PBMNCs were divided into two equal parts for NK cell and CTLs expansion, and seeded at a density of $1 \times 10^{6}$ cells $/ \mathrm{ml}$ in the cell initial medium. For NK cell expansion, the medium contained $0.01 \mathrm{KE} / \mathrm{ml} \mathrm{OK}-432$ (Chugai Pharmaceutical Co., Ltd., Tokyo, Japan) and $700 \mathrm{IU} / \mathrm{ml}$ recombinant human interleukin-2 (rhIL-2; Chiron Corp, Emeryville, CA, USA) supplemented with $5 \%$ heat-inactivated autologous plasma, and the cells were cultured in an anti-CD16 monoclonal antibody (Beckman Coulter, Inc., Brea, CA, USA)-immobilized culture flask. For CTL expansion, PBMNCs were culture in cell initial medium containing $700 \mathrm{IU} / \mathrm{ml}$ rhIL-2 in an anti-CD3 monoclonal antibody-immobilized flask. The cells were incubated at $37^{\circ} \mathrm{C}$ in an atmosphere with $5 \%$ $\mathrm{CO}_{2}$ for 3 days. After 3 days, the culture medium was changed and subcultured every 2-3 days in cell subculture medium (provided in the kit) containing $350 \mathrm{IU} / \mathrm{ml} \mathrm{rhIL}-2$ supplemented with $5 \%$ heat-inactivated autologous plasma to maintain a concentration of $0.8-1.0 \times 10^{6}$ cells $/ \mathrm{ml}$, without discarding the old medium. When the number of cell increased logarithmically, the cultured cells were transferred into culture bags (Nipro, Osaka, Japan) until day 21 of culture.

Phenotypic analysis. The phenotype of expanded cells and PBMNCs at baseline (day 0) and at the end of the culture (day 21) was analyzed by flow cytometry. Monoclonal antibodies specific for CD3, CD8, CD56 and CD4 that were conjugated with Pacific Blue, fluorescein isothiocyanate, R-phycoerythrin and Allophycocyanin-Alexa Flour 750, respectively (Beckman Coulter, Inc.), and the corresponding isotype were used for the characterization of cell population. Cells were analyzed by Navios flow cytometer (Beckman Coulter, Inc.), and data were acquired by Navios software (version 3.2) according to the manufacturer's instructions.

Quality control testing. Quality control testing was examined by assessing samples obtained during the culture period and at the final product. For sterility examination, the BacT/ALERT Plus microbiological detection system (bioMérieux, Marcy-l'Étoile, France) was used, while a MycoAlert Mycoplasma Detection kit (Lonza Group, Ltd., Basel, Switzerland) was applied for mycoplasma contamination testing. The viability of expanded cells was measured by trypan blue exclusion assay and tested for endotoxin by a kinetic colorimetric LAL assay using the Endosafe-PTS portable test system (Charles River Laboratories, Inc., Wilmington, MA, USA). 
Safety evaluation. The safety evaluation was conducted using the ECOG/PS scale (27). The evaluations were conducted at the time patients were enrolled in the research (from April to August 2016), and then 18 months later.

Statistical analysis. Statistical analyses were performed with STATA software (version 12.0; StataCorp LLC, College Station, TX, USA) to determine the Prob $>F, \mathrm{R}^{2}$ coefficients of correlation and $\mathrm{P}$-value. A value of $\mathrm{P}<0.05$ was considered to indicate a difference that was statistically significant.

\section{Results}

Patient characteristics. Between December 2015 and June 2016, a total of 7 patients (6 females and 1 male) were enrolled into the present study. Table I lists the patient clinical characteristics. The mean age of the participants was $55.5 \pm 17.4$ years, with an age range of $30-84$ years. All patients included in the present study had an ECOG/PS value of $\geq 3$ (Table I), suggesting that they were only capable of limited self-care, confined to bed or chair for $>50 \%$ of their waking hours (27).

Immune cell expansion. Subsequent to seeding, the PBMNC number was counted every 2 days starting on day 3 of the culture using trypan blue staining. It was observed that the number of cells decreased after 3 days of culture at the stimulation step. The total cell number at day 3 was $\sim 68.4 \%$ as compared with that on day 0 . Subsequently, the cell number began to growth at day 7 and reached logarithm growth on continuous days until the day 20. In this period, cells grew as large clumps, which is a characteristic of proliferating immune cells (Fig. 1). In particular, the growth stopped in two samples in the CTL culture on day 18 and the cell number decreased subsequently (Fig. 2).

From $70 \mathrm{ml}$ of peripheral blood, PBMNCs were collected with the Ficoll-Paque method and divided into two equal parts for NK cell and CTL expansion. The average number of cells at seeding for each culture condition was $53.4 \pm 13.5 \times 10^{6}$. After 21 days of culture, the average total number of cells in the NK culture was $4,137.2 \times 10^{6}\left(2,123.0-9,373.2 \times 10^{6}\right.$ cells $)$, which increased by 79.8 -fold (range, 34.4- to 142.7-fold), while the cell viability was $94.7 \%$ (91-97.3\%). In the CTL culture, the average total number of cells was $10,896.1 \times 10^{6}$ (2,544.0-30,240.0x $10^{6}$ cells), which increased by 192.5 -fold (range, 38.7- to 448.0 -fold), with a cell viability of $95.7 \%$ (92.8-98\%; Table II).

Characteristics of immune cell population. The targeted immune cells increased sharply in the selected culture medium (Fig. 3). The average absolute number of NK cells in the NK culture at day 21 was $3,587.4 \times 10^{6}$, demonstrating an increase of 637.5 -fold (range, 167.1- to 1,613-fold) and accounting for $84.3 \pm 14.9 \%$ (54-96.7\%) of the total cell culture compared with the value of $17.9 \pm 9.5 \%$ (5.5-33.9\%) at seeding. Similarly, the absolute number of CTLs in the CTL culture was $7,561.4 \times 10^{6}$, demonstrating an increase of 742.3 -fold (range, 191.6- to 1,545.1-fold) and accounting for $72.2 \pm 9.1 \%$ (57.1-85.6\%) of the total cell culture compared with the

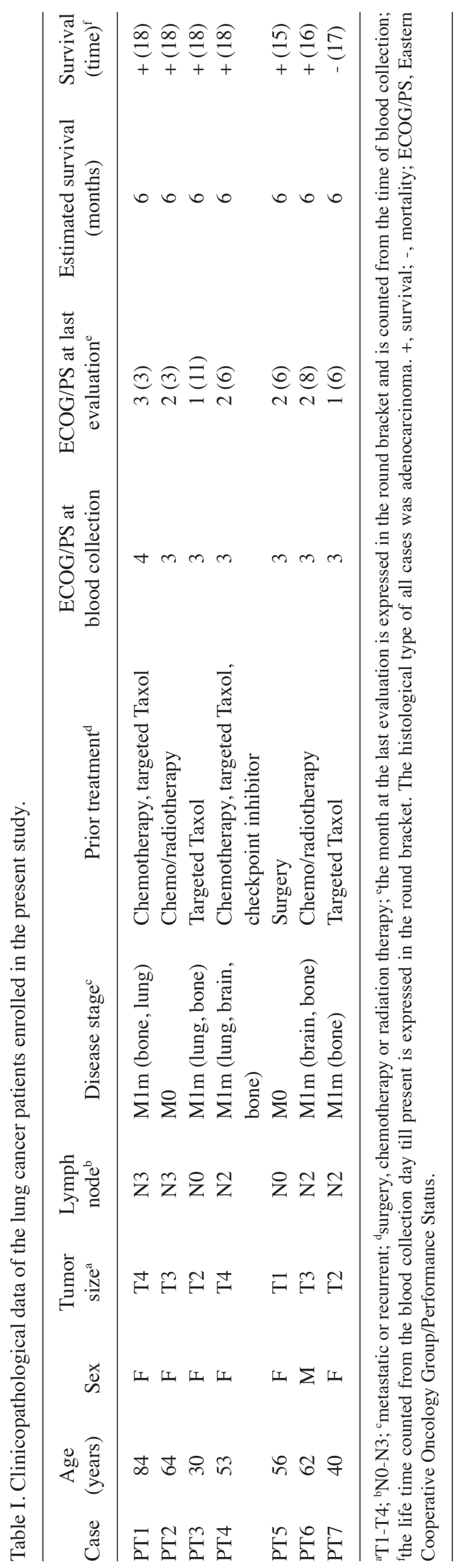


Table II. Number of cell population pre- and post-expansion.

\begin{tabular}{lccccc}
\hline & $\begin{array}{c}\text { PBMNC count/ } \\
\text { collection for } \\
\text { each culture } \\
\left(\mathrm{x} 10^{6}\right)\end{array}$ & $\begin{array}{c}\text { Final cell count } \\
\text { for NK cell } \\
\text { culture }\left(\mathrm{x} 10^{6}\right)\end{array}$ & $\begin{array}{c}\text { Total cell fold } \\
\text { expansion in NK } \\
\text { cell culture }\left(\mathrm{x} 10^{6}\right)\end{array}$ & $\begin{array}{c}\text { Final cell count } \\
\text { for CTLs culture } \\
\left(\mathrm{x} 10^{6}\right)\end{array}$ & $\begin{array}{c}\text { Total cell fold } \\
\text { expansion in } \alpha \beta T \\
\text { cell culture }\left(\mathrm{x} 10^{6}\right)\end{array}$ \\
\hline PT1 & 65.7 & $9,373.2$ & 142.7 & 2,544 & 38.7 \\
PT2 & 67.5 & 3,210 & 47.6 & 30,240 & 448.0 \\
PT3 & 59.0 & 3,840 & 65.1 & 17,088 & 289.6 \\
PT4 & 61.8 & 2,123 & 34.4 & 9,345 & 146.3 \\
PT5 & 47.8 & 3,152 & 65.9 & 7,008 & 100.2 \\
PT6 & 33.2 & 3,720 & 112.0 & 3,328 & 172.8 \\
PT7 & 38.9 & 3,542 & 91.1 & 6,720 & \\
\hline
\end{tabular}

PBMNC, peripheral blood mononuclear cell; NK, natural killer; CTL, cytotoxic T lymphocyte; PT, patient.
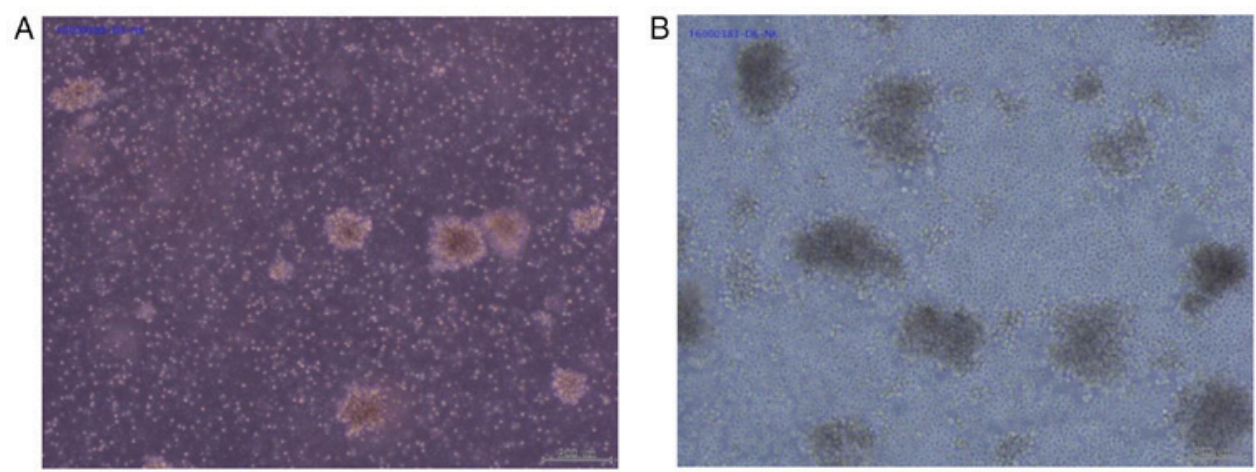

Figure 1. Cell growth in natural killer cell culture. The morphology of the cell population at (A) day 3 and (B) day 6 of culture is shown for a representative case (patient 1).
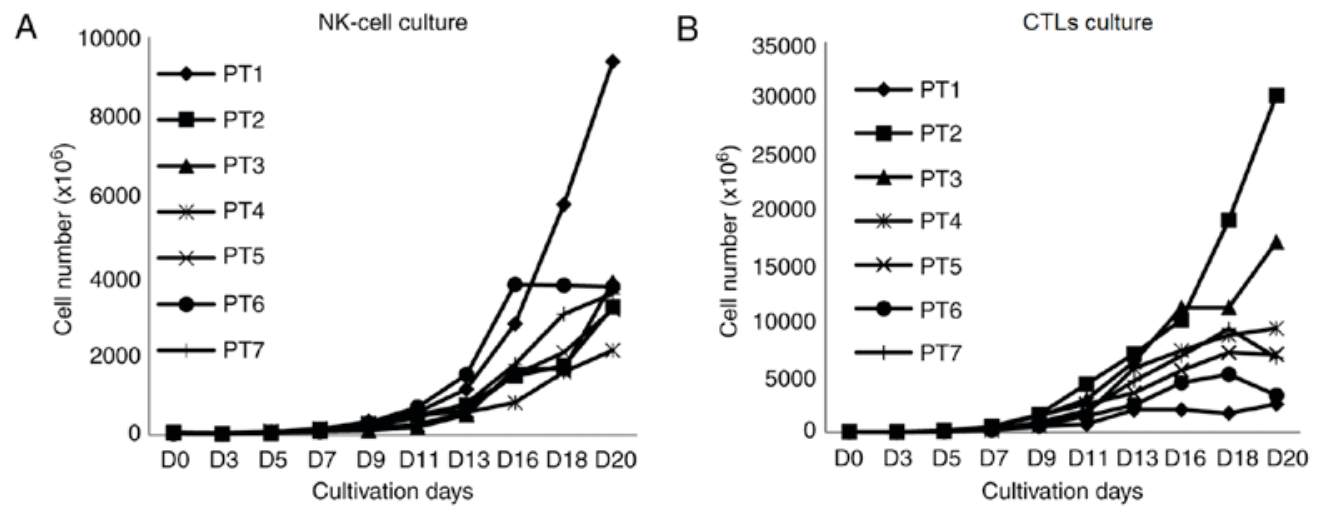

Figure 2. Cell growth curves in the (A) NK cell and (B) CTL culture of 7 lung cancer samples, demonstrating the association between the number of culture days and the total number of cultured cells. D, day after the start of the culture; PT, patient; NK, natural killer; CTL, cytotoxic T lymphocyte.

percentage of $22.7 \pm 3.5 \%(18.7-26.4 \%)$ at seeding (Tables III and IV).

In the NK cell culture, a strong correlation was recognized between the number of NK and cytokine-induced killer (CIK) cells, with a coefficient of determination $\left(\mathrm{R}^{2}\right)$ of 0.9 . The number of CIK cells decreased when NK cells were dominant in the population and vice versa (coefficient $=-1.17$; $\mathrm{P}<0.001$; Fig. 4A), whereas other $\mathrm{CD}^{+}$cells did not display this correlation $(\mathrm{P}>0.05)$. By contrast, in the CTL culture, there was no correlation between CTLs and CIK cells (P>0.05; Fig. 4B). In the two culture conditions, the initial number of immune cells at seeding was not correlated with the number of expanded immune cells subsequent to culturing (Fig. 4C and D). Notably, the percentage of CD3 ${ }^{-} \mathrm{CD} 56^{\text {bright }}$ increased strongly in the NK cell culture, accounting for $82.1 \%$ of cells $(52.7-92.8 \% ; n=7)$ in average. The absolute number 

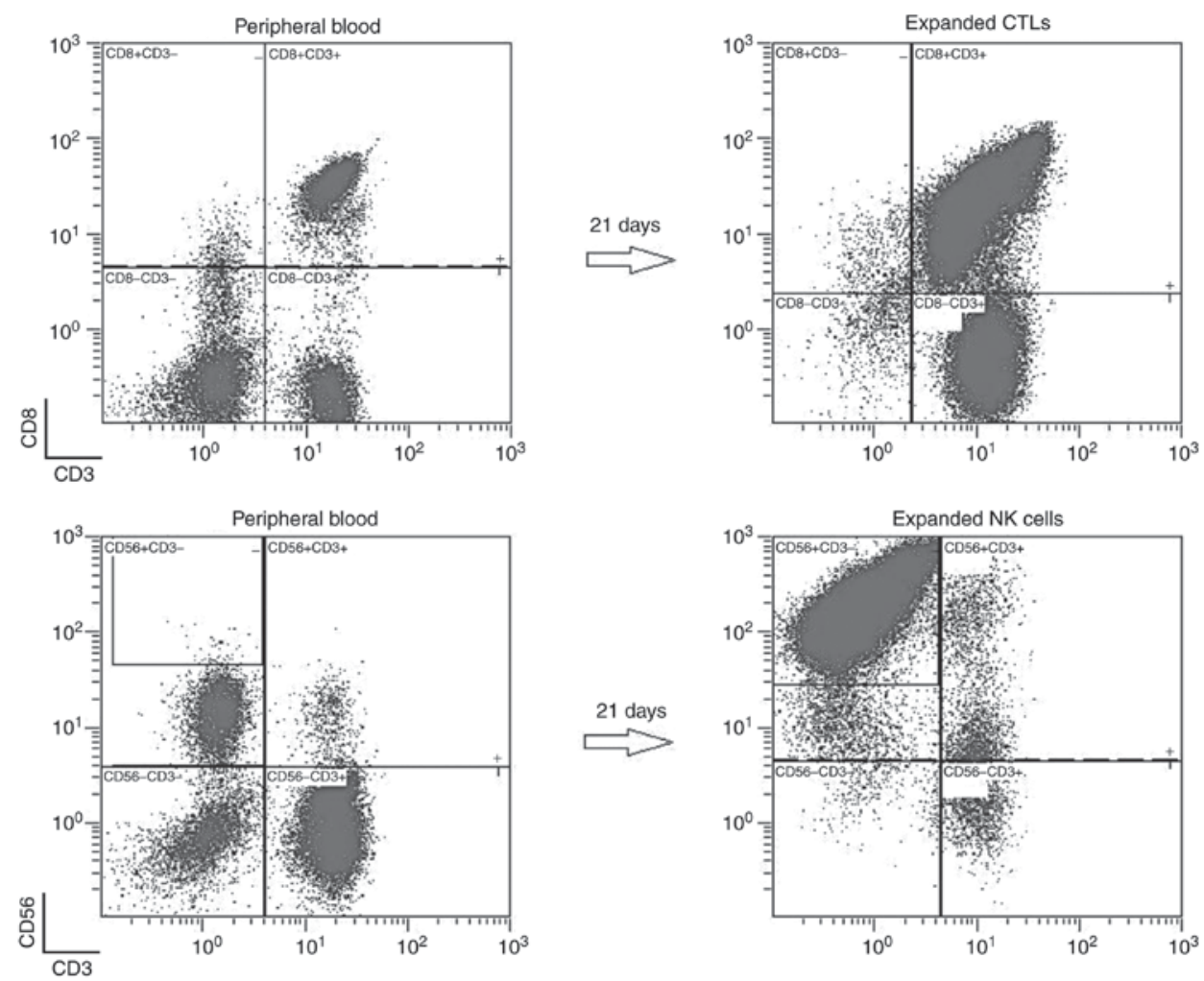

Figure 3. Phenotyping analysis of immune cell population in a representative case (patient 4). Cells at day 21 of cultivation were harvested and incubated with different marker for identifying (A) CTLs or (B) NK-cell. NK, natural killer; CTL, cytotoxic T lymphocyte.
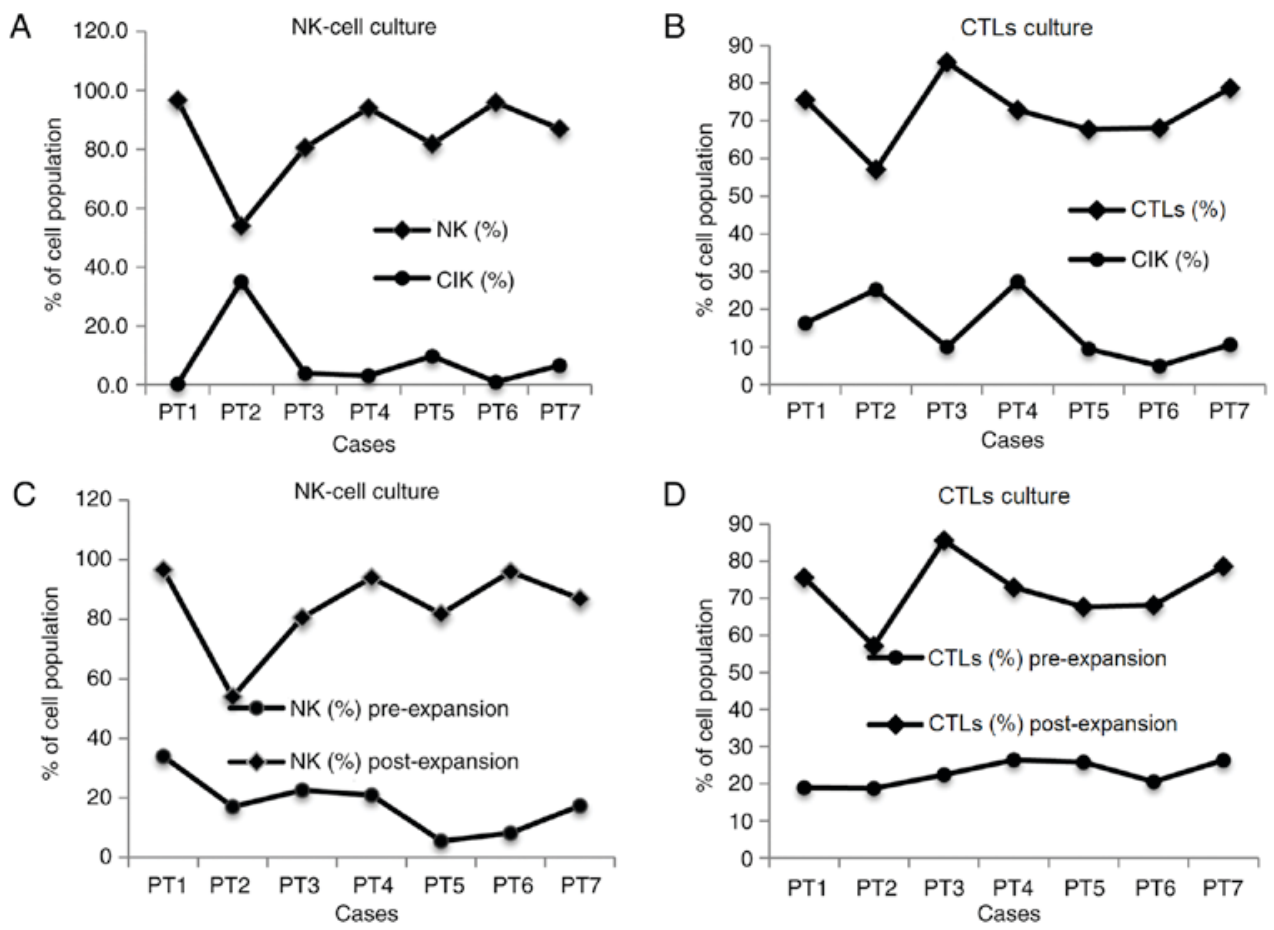

Figure 4. Correlation between cell populations in the NK cell and CTL cultures. (A) The average CIK proportion was inversely correlated with the proportion of NK cells in the NK cell cultured populations $\left(\mathrm{R}^{2}=0.9 ; \mathrm{P}<0.05\right)$. (B) In the CTL culture, the correlation between the quantity of CTLs and CIK cells was low $\left(\mathrm{R}^{2}=0.2 ; \mathrm{P}>0.05\right)$. There was no clear correlation between the rates of initial NK cells and CTLs in peripheral blood mononuclear cells with the corresponding number of cells following ex vivo expansion in the (C) NK cell culture or (D) CTL cell culture $\left(\mathrm{R}^{2}<0.2 ; \mathrm{P}>0.05\right)$. PT, patient; $\mathrm{NK}$, natural killer; CTL, cytotoxic T lymphocyte; CIK, cytokine-induced killer.

of this cell type was $3,094.3 \times 10^{6}\left(913.5-8,438.5 \times 10^{6}\right)$, which increased by 408.9 -fold (range, 121.4- to 958 -fold; Table V).
All cultures were negative for mycoplasma and bacteria/fungi, while the endotoxin level was $<0.5 \mathrm{EU} / \mathrm{ml}$. 
Safety evaluation. The 7 patients presented an ECOG/PS score of 3 (6 patients) and 4 (1 patient) at the day of blood collection. This score decreased at the last evaluation, with 1 patient demonstrating a score of 3, 3 patients with a score of 2 and 2 patients with a score of 1 . All patients had been estimated to live only 6 months upon joining the present study. At the last follow-up (18 months), 6 patients are alive, whereas 1 patient succumbed after 17 months (Table I).

\section{Discussion}

In the present study, the efficacy of ex vivo expansion of NK cells and CTLs from the peripheral blood of Vietnamese cancer patients using BINKIT was evaluated. The two culture conditions investigated (NK cell and CTL cultures) demonstrated no clear correlation between the rate of initial immune cells in the peripheral blood and the corresponding number following ex vivo expansion $(\mathrm{P}>0.05)$.

A relatively pure $\mathrm{NK}\left(\mathrm{CD}^{2} 6^{+} \mathrm{CD} 3^{-}\right)$cell population of $84.3 \pm 14.9 \%$ was generated, which was initially $17.9 \pm 9.5 \%$ in the whole blood without any prior NK purification method. In 3 out of 7 cases (42.8\%), the proportion of NK following culture reached $>94 \%$. The mean NK cell expansion was 637.5-fold (range, 167.1- to 1,613-fold) after 21 days of culture. Furthermore, in the specific medium for NK cell expansion, the percentage of other lymphocyte, including $\mathrm{CD}^{+} \mathrm{CD}^{+}$, $\mathrm{CD}^{+}{ }^{+} \mathrm{CD} 8^{+}$and $\mathrm{CD}^{+}{ }^{+} \mathrm{CD} 56^{+}$cells, was minimal (mean value, $8.63,1.46$ and $3.74 \%$, respectively). These data indicated that NK cells were selectively expanded and became the major population.

Recently, CIK cells have been investigated in the treatment of cancer as a potential immune cell therapy $(2,3)$. Notably, the present study identified a close association between the quantity of CIK cells and the number of NK cells in the NK cell culture $(\mathrm{P}<0.05)$. However, in the CTL culture, no such correlation between the CIK and CTL cell numbers was observed.

There were several methods to achieve large-scale expansion of NK cells ex vivo in order to develop NK cell therapeutics $(10,22)$. PBMNCs have been used as a general source of NK cells for expansion; however, these are composed of numerous immune cell types. The most important target of various studies is identifying a method for specifically culturing NK cells in PBMNCs. Carlens et al (20) observed that, after 21 days of culture from total PBMNCs with IL-12 and OKT3, NK cells were stimulated up to 700 -fold with a $55 \%$ purity. Another study by Fujisaki et al (21) in 2009 revealed that, upon K562-mb15-41BBL cell stimulation, NK cells increased by 277 -fold after 21 days of culture. Torrelli et al (22) used irradiated autologous feeder cells along with IL-2 and IL-15 for $\mathrm{NK}$ cell expansion following $\mathrm{CD}^{+} \mathrm{T}$ cell depletion and obtained an NK cell increase by 15.7 -fold after 14 days of culture. Terunuma and his co-workers $(4,25,26)$ demonstrated that ex vivo culture of NK cells from peripheral blood using BINKIT is a safe culture method, and that NK cells expanded by several hundred folds after 2 weeks under GMP conditions. Compared with these previously published studies, the present study results obtained the highest purity of the NK cell population and a high number of NK cells, which was suitable for clinical application.

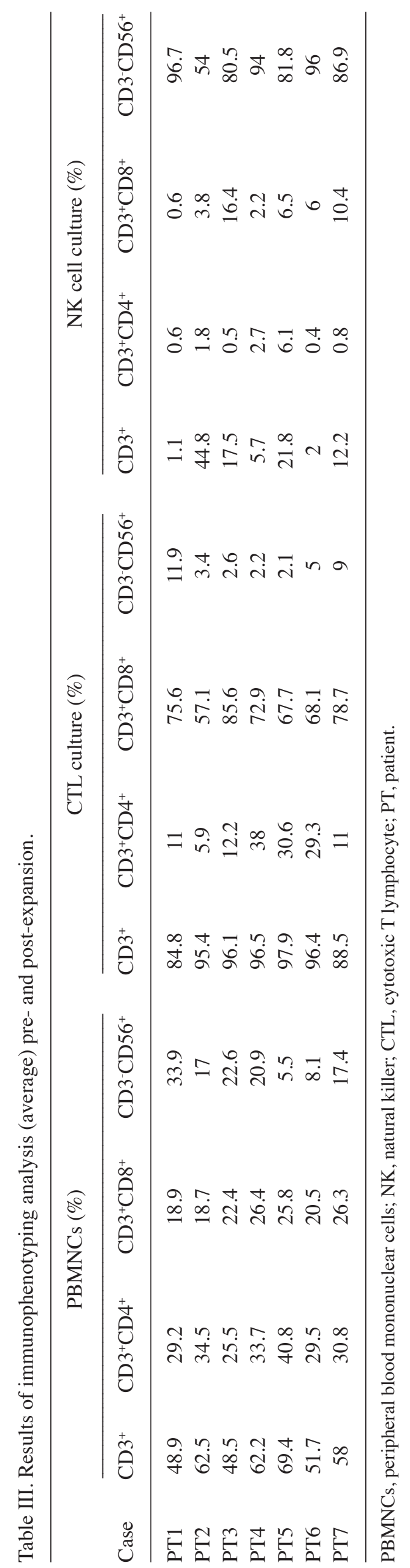


Table IV. Absolute cell number (average) pre- and post-expansion.

\begin{tabular}{|c|c|c|c|c|c|c|}
\hline \multirow[b]{2}{*}{ Case } & \multicolumn{3}{|c|}{$\mathrm{CTL}$ culture $\left(\mathrm{CD}^{+}{ }^{+} \mathrm{CD} 8^{+}\right), \times 10^{6}$} & \multicolumn{3}{|c|}{ NK-cell culture $\left(\mathrm{CD} 3 \mathrm{CD}^{-} 6^{+}\right), \times 10^{6}$} \\
\hline & Pre-expansion & Post-expansion & Fold increase & Pre-expansion & Post-expansion & Fold increase \\
\hline PT1 & 10.0 & $1,923.3$ & 191.6 & 17.71 & $9,063.9$ & 511.7 \\
\hline PT2 & 11.4 & $17,267.0$ & $1,513.3$ & 10.37 & $1,733.4$ & 167.1 \\
\hline PT3 & 9.5 & $14,627.3$ & $1,545.0$ & 9.55 & $3,091.2$ & 323.6 \\
\hline PT4 & 13.7 & $6,812.5$ & 498.9 & 10.82 & $1,995.6$ & 184.4 \\
\hline PT5 & 10.6 & $4,744.4$ & 446.7 & 2.26 & $2,578.3$ & $1,138.7$ \\
\hline PT6 & 5.6 & $2,266.4$ & 404.5 & 2.21 & $3,571.2$ & $1,613.0$ \\
\hline PT7 & 8.9 & $5,288.6$ & 596.0 & 5.87 & $3,078.0$ & 524.3 \\
\hline
\end{tabular}

PBMNCs, peripheral blood mononuclear cells; NK, natural killer; CTL, cytotoxic T lymphocyte; PT, patient.

Table V. Percentage of active NK cells (CD3-CD56 ${ }^{+}$bright) pre- and post-expansion.

\begin{tabular}{|c|c|c|c|c|}
\hline \multirow[b]{2}{*}{ Cases } & \multicolumn{2}{|c|}{ Pre-expansion } & \multicolumn{2}{|c|}{ Post-expansion } \\
\hline & Percentage $(\%)$ & Absolute number $\left(\mathrm{x} 10^{6}\right)$ & Percentage $(\%)$ & Absolute number $\left(\mathrm{x} 10^{6}\right)$ \\
\hline PT1 & 0.5 & 0.09 & 93.1 & $8,438.5$ \\
\hline PT2 & 0.1 & 0.01 & 52.7 & 913.5 \\
\hline PT3 & 0.2 & 0.02 & 78.7 & $2,432.8$ \\
\hline PT4 & 0.3 & 0.03 & 91.8 & $1,831.6$ \\
\hline PT5 & 0.2 & 0.00 & 77.8 & $2,005.9$ \\
\hline PT6 & 0.1 & 0.00 & 95.8 & $3,421.2$ \\
\hline PT7 & 0.7 & 0.04 & 85.0 & $2,616.3$ \\
\hline
\end{tabular}

NK, natural killer; PT, patient.

Ex vivo expansion of the CTL population in the present study had a slightly lower purity as compared with that in $\mathrm{NK}$ cells, with a mean proportion of CTLs $\left(\mathrm{CD}^{+} \mathrm{CD}^{+}\right)$of $72.2 \pm 9.1 \%$ of the total number of cells and a highest reported value of $85.6 \%$. In the group of patients included in the study, the mean fold expansion of immune cells from PBMNCs was 742.3-fold for CTL cells, while the absolute mean number of CTLs was 7,561.4x106.

Several CTL expansion methods have been used in order to develop a relevant time of culture and number of CTLs suitable for clinical application. An earlier method required a 45-60-day expansion protocol for CTLs (28). In order to improve this culture time, Dudley et al (29) presented the rapid expansion protocol using anti-CD3 antibody with high-dose IL-2 and allogeneic feeder cells to generate T cells. After 14 days of cultivation, the cell number increased by 1,320-fold (29). In order to avoid using a high dose of IL-2 and exogenous feeder cells, Porter et al (30) co-stimulated ex vivo T cells with CD3 and CD28 antibodies and obtained an expansion number of a 113-fold increase. However, this method induced both $\mathrm{CD}^{+} \mathrm{CD}^{+}$and $\mathrm{CD}^{+} \mathrm{CD}^{+} \mathrm{T}$ cells. Another study also used CD3 and CD28 antibodies to stimulate T cells together with the removal of CD25 with the aim of increasing the antigen-specific CD8 ${ }^{+} \mathrm{T}$ cells, and successfully increased the specific T cells by 335-fold (31). Recently, Smith et al (32) investigated the method of using a xeno-free serum replacement as an alternative to human serum and fetal bovine serum in culturing, and obtained an $>300$-fold increase in the number of T cells following costimulation with CD3 and CD28 antibodies.

In comparison with alternative methods to expand NK cells and CTLs in clinical practice, the present study data suggested that large-scale expansion of these cells directly from PBMNCs using BINKIT without prior purification and feeder cells is a safe and effective method for immune cell therapy in cancer treatment.

Notably, it was observed that CD56 was highly expressed (namely CD56 ${ }^{\text {bright }}$ ) in the expanded NK cell population. In whole blood, only $<1 \%$ of CD56 $6^{\text {bright }}$ cells were identified; however, following culturing, the NK population contained mainly CD56 ${ }^{\text {bright }}$ cells (82.1\%). The CD56 ${ }^{\text {bright }} \mathrm{NK}$ cells are considered the efficient cytokine producers, as their major secretory molecules are IFN- $\gamma, \mathrm{TNF}-\alpha$, granulocyte macrophage colony-stimulating factor and IL-10, all of which serve important roles in destroying cancerous cells (33). In the study by Chan et al in 2007 (34), CD56 ${ }^{\text {bright }}$ NK cells have longer telomeres as compared with $\mathrm{CD} 56^{\mathrm{dim}}$ cells, and can be differentiated into CD56 $6^{\mathrm{dim}}$ in vivo without cell proliferation. 
Notably, a previous study demonstrated that CD56 ${ }^{\mathrm{dim}}$ cells generated from CD56 ${ }^{\text {bright }}$ cells had increased cytotoxicity (33). Therefore, it is suggested that NK expanded cells have a higher cytotoxicity and are more efficient in killing cancer cells.

Prior to infusion of cultured cells, an endotoxin, mycoplasma and sterility detection tests were conducted to confirm the safety of the intravenous injection. All products in the present study were negative for mycoplasma and bacteria, while the concentration of endotoxin was $<0.5 \mathrm{EU} / \mathrm{ml}$, which is considered to be a safe value for intravenous injection. Following administration of ex vivo expanded cells in all patients, no adverse reactions were observed. Furthermore, improvement in the quality of life was observed in almost all patients. These observations prove the safety of the intravenous administration of the ex vivo-expanded NK and CTL cells to cancer patients in the present study. The safety subsequent to receiving the culture cells was also examined, and patients were followed up. Almost all patients demonstrated improved life quality, with the majority of patients presenting a score of 1 or 2 in the ECOG/PS scale. Furthermore, 6 patients were alive at the last follow-up, and only 1 patient succumbed at 17 months after the treatment. These results suggest that AIET conducted in the present study was safe.

In conclusion, the present data demonstrated that BINKIT is an appropriate and efficient method for ex vivo expansion of NK cells and CTLs from the PBMNCs of lung cancer patients, and evidently improved their quality of life. The advantages of the BINKIT protocol is the high level of purity and the safety for injection of the expanded NK cell and CTL culture after 3 weeks. To determine the activity of expanded immune cells and the effects of AIET in cancer treatment, further investigation must be conducted and clinical data collected. Given the positive results of this first study using AIET in cancer patients in Vietnam, it is strongly suggested that this method is a promising tool for immune cell-based cancer immunotherapy for cancer patients.

\section{Acknowledgements}

The authors would like to thank Dr. Hiroshi Terunuma and Mr. Tsubasa Takane (Biotherapy Institute of Japan, Tokyo, Japan) for advices in cell culture.

\section{Funding}

The present study was supported by Vingroup JSC (grant no. DT-01; Hanoi, Vietnam)

\section{Availability of data and materials}

The datasets used and/or analyzed during the current study are available from the corresponding author on reasonable request.

\section{Authors' contributions}

Conceived and designed the experiments: NTL, HTMN, PNL, DTH. Performed the experiments: HTMN, BVA, DTH, CTT. Analyzed the data: HTMN, BVA, TLH. Wrote the paper: HTMN, TLH. Manuscript editing: NTL, HTMN.

\section{Ethics approval and consent to participate}

The study was approved by the Ethics Committee of the Vinmec International Hospital. This study was conducted with the permission of the Vietnam Ministry of Health (document no. 2517/BYT-KCB; Hanoi, Vietnam). Patients provided written informed consent.

\section{Consent for publication}

Patients provided written informed consent.

\section{Competing interests}

The authors declare that they have no competing interests.

\section{References}

1. Ferlay J, Soerjomataram I, Ervik M, Dikshit R, Eser S, Mathers C, Rebelo M, Parkin DM, Forman D and Bray F: GLOBOCAN 2012 v1.0, Cancer Incidence and Mortality Worldwide: IARC CancerBase No. 11. IARC, Lyon, France, 2013.

2. Mellman I, Coukos G and Dranoff G: Cancer immunotherapy comes of age. Nature 480: 480-489, 2011.

3. Dudley ME and Rosenberg SA: Adoptive-cell-transfer therapy for the treatment of patients with cancer. Nat Rev Cancer 3: 666-675, 2003.

4. Terunuma H: Autologous immune enhancement therapy for cancer-our experience since 2004. J Stem Cells Regen Med 8: 205-206, 2012.

5. Kalinski P, Mailliard RB, Giermasz A, Zeh HJ, Basse P, Bartlett DL, Kirkwood JM, Lotze MT and Herberman RB: Natural killer-dendritic cell cross-talk in cancer immunotherapy. Expert Opin Biol Ther 5: 1303-1315, 2005.

6. Kalos $\mathrm{M}$ and June $\mathrm{CH}$ : Adoptive T cell transfer for cancer immunotherapy in the era of synthetic biology. Immunity 39: 49-60, 2013.

7. Cooper MA, Fehniger TA and Caligiuri MA: The biology of human natural killer-cell subsets. Trends Immunol 22: 633-640, 2001.

8. Screpanti V, Wallin RP, Ljunggren HG and Grandien A: A central role for death receptor-mediated apoptosis in the rejection of tumors by NK cells. J Immunol 167: 2068-2073, 2001.

9. Bouwer AL, Saunderson SC, Caldwell FJ, Damani TT, Pelham SJ, Dunn AC, Jack RW, Stoitzner P and McLellan AD: NK cells are required for dendritic cell-based immunotherapy at the time of tumor challenge. J Immunol 192: 2514-2521, 2014.

10. Sutlu T and Alici E: Natural killer cell-based immunotherapy in cancer: Current insights and future prospects. J Intern Med 266: 154-181, 2009.

11. Qin Z, Schwartzkopff J, Pradera F, Kammertoens T, Seliger B, Pircher $\mathrm{H}$ and Blankenstein T: A critical requirement of interferon gamma-mediated angiostasis for tumor rejection by CD8 ${ }^{+} \mathrm{T}$ cells. Cancer Res 63: 4095-4100, 2003

12. Maher J and Davies ET: Targeting cytotoxic T lymphocytes for cancer immunotherapy. Br J Cancer 91: 817-821, 2004.

13. Weigelin B, Krause M and Friedl P: Cytotoxic T lymphocyte migration and effector function in the tumor microenvironment. Immunol Lett 138: 19-21, 2011.

14. Anikeeva N, Somersalo K, Sims TN, Thomas VK, Dustin ML and Sykulev Y: Distinct role of lymphocyte function-associated antigen-1 in mediating effective cytolytic activity by cytotoxic T lymphocytes. Proc Natl Acad Sci USA 102: 6437-6442, 2005.

15. Ratner A and Clark WR: Role of TNF-alpha in $\mathrm{CD}^{+}$cytotoxic T lymphocyte-mediated lysis. J Immunol 150: 4303-4314, 1993.

16. Castriconi R, Daga A, Dondero A, Zona G, Poliani PL, Melotti A, Griffero F, Marubbi D, Spaziante R, Bellora F, et al: NK cells recognize and kill human glioblastoma cells with stem cell-like properties. J Immunol 182: 3530-3539, 2009.

17. Weng D, Song B, Durfee J, Sugiyama V, Wu Z, Koido S, Calderwood SK and Gong J: Induction of cytotoxic T lymphocytes against ovarian cancer-initiating cells. Int J Cancer 129: 1990-2001, 2011.

18. Ahmed N, Salsman VS, Kew Y, Shaffer D, Powell S, Zhang YJ, Grossman RG, Heslop HE and Gottschalk S: HER2-specific T cells target primary glioblastoma stem cells and induce regression of autologous experimental tumors. Clin Cancer Res 16: 474-485, 2010. 
19. Cho D and Campana D: Expansion and activation of natural killer cells for cancer immunotherapy. Korean J Lab Med 29: 89-96, 2009.

20. Carlens S, Gilljam M, Chambers BJ, Aschan J, Guven H, Ljunggren HG, Christensson B and Dilber MS: A new method for in vitro expansion of cytotoxic human CD3-CD56 ${ }^{+}$natural killer cells. Hum Immunol 62: 1092-1098, 2001.

21. Fujisaki H, Kakuda H, Shimasaki N, Imai C, Ma J, Lockey T, Eldridge P, Leung WH and Campana D: Expansion of highly cytotoxic human natural killer cells for cancer cell therapy. Cancer Res 69: 4010-4017, 2009.

22. Torelli GF, Rozera C, Santodonato L, Peragine N, D'agostino G, Montefiore E, Napolitano MR, Monque DM, Carlei D, Mariglia $\mathrm{P}$, et al: A good manufacturing practice method to ex vivo expand natural killer cells for clinical use. Blood Transfus 13: 464-471, 2015.

23. Koehl U, Brehm C, Huenecke S, Zimmermann SY, Kloess S, Bremm M, Ullrich E, Soerensen J, Quaiser A, Erben S, et al: Clinical grade purification and expansion of NK cell products for an optimized manufacturing protocol. Front Oncol 3: 118, 2013.

24. Subramani B, Ratnavelu K, Pullai CR, Krishnan K, Sugadan SD Deng $X$ and Hiroshi T: Autologous immune enhancement therapy: A case report of a stage IV colonic cancer. Oncol Lett 5: 1611-1614, 2013

25. Dedeepiya V, Terunuma H, Manjunath S, Senthilkumar R, Thamaraikannan P, Srinivasan T, HelenReena C, Preethy S and Abraham S: Autologous immune enhancement therapy for cancer using NK cells and CTLs without feeder layers; our six year experience in India. J Stem Cells Regen Med 7: 95, 2011.

26. Terunuma H, Deng X, Nishino $N$ and Watanabe K: NK cell-based autologous immune enhancement therapy (AIET) for cancer. J Stem Cells Regen Med 9: 9-13, 2013.

27. Oken MM, Creech RH, Tormey DC, Horton J, Davis TE, McFadden ET and Carbone PP: Toxicity and response criteria of the eastern cooperative oncology group. Am J Clin Oncol 5 $649-655,1982$
28. Topalian SL, Muul LM, Solomon D and Rosenberg SA: Expansion of human tumor infiltrating lymphocytes for use in immunotherapy trials. J Immunol Methods 102: 127-141, 1987.

29. Dudley ME, Wunderlich JR, Shelton TE, Even J and Rosenberg SA: Generation of tumor-infiltrating lymphocyte cultures for use in adoptive transfer therapy for melanoma patients. J Immunother 26: 332-342, 2003.

30. Porter DL, Levine BL, Bunin N, Stadtmauer EA, Luger SM, Goldstein S, Loren A, Phillips J, Nasta S, Perl A, et al: A phase 1 trial of donor lymphocyte infusions expanded and activated ex vivo via CD3/CD28 costimulation. Blood 107: 1325-1331, 2006.

31. Rasmussen AM, Borelli G, Hoel HJ, Lislerud K, Gaudernack G, Kvalheim G and Aarvak T: Ex vivo expansion protocol for human tumor specific $\mathrm{T}$ cells for adoptive T cell therapy. J Immunol Methods 355: 52-60, 2010.

32. Smith C, Økern G, Rehan S, Beagley L, Lee SK, Aarvak T, Schjetne KW and Khanna R: Ex vivo expansion of human T cells for adoptive immunotherapy using the novel Xeno-free CTS immune cell serum replacement. Clin Transl Immunol 4: e31, 2015.

33. Michel T, Poli A, Cuapio A, Briquemont B, Iserentant G, Ollert $M$ and Zimmer J: Human CD56bright NK Cells: An Update. J Immunol 196: 2923-2931, 2016.

34. Chan A, Hong DL, Atzberger A, Kollnberger S, Filer AD, Buckley CD, McMichael A, Enver T and Bowness P: CD56 $6^{\text {bright }}$ human NK cells differentiate into CD56dim cells: Role of contact with peripheral fibroblasts. J Immunol 179: 89-94, 2007.

(c) (3) (9) This work is licensed under a Creative Commons

C. At No NO Attribution-NonCommercial-NoDerivatives 4.0 International (CC BY-NC-ND 4.0) License. 